\title{
Articles
}

Central European Review of Economics \& Finance

Vol. 19, No. 3 (2017), pp. 31-42. D0I: 10.24136/ceref.2017.011

Ewaryst Kowalczyk ${ }^{1}$

\section{SOCIAL CLAUSES IN PUBLIC PROCUREMENT AS A PREMISE TO OPTIMISE FINANCING OF THE TASKS OF GOVERNMENT UNITS}

Accepting on 26 February 2014 by the European Parliament and the Council a new directive concerning procurement and the necessity to transposition its provisions to the Polish legal system caused the appearance of vital changes in the area of procurement referring to social aspects. The most momentous changes are connected with the specified in regulations possibility to describe a subjectmatter of the contract including social requirements, possibility to exclude contractors exclusion and forming conditions of participating in proceedings, and possibility of forming offers assessment criteria referring to social aspects. Therefor the social aspects became a momentous, yet facultative premise of the optimisation of the public expenses within public contracts.

JEL Classification Codes: H72, H57.

Keywords: Public procurement, Govermment units, Optimise financing.

\section{Introduction}

Subjects of public administration constitute the widest group among those awarding with public contracts. It results from the fact that legal regulations concerning public procurement are in the first place directed to the units of the public finances sector (Public procurement law, Art. 3 sec. 1 point 1), and this category covers among others local government units (Public finances law, Art. 9 of 27). Hence, the area of public procurement is the sphere of the

\footnotetext{
${ }^{1}$ PhD., Administrative and Financial Law Department, Law and Administration Faculty, University of Zielona Góra.
} 
activity of local government units working in non-governmental forms, which are shown in entering contracts of civil law character and organization of civil law procedures aiming at selecting executors who are the parties of such contracts. A civil law character of public procurement does not, however, determine a total freedom of the contracting parties in this area. The issue of awarding public contracts includes also and interference of a legislator into the process of awarding a contract by imposing certain duties on contracting institutions or creating rights in order to realise the functions of the public procurement system (Panasiuk, 2007, p. 43 and the following).

The issue of public procurement is presently undertaken mainly by the act of 29 January 2004 - Public procurement law (hereinafter referred to as p.p.l). The act has been binding as of 2 March 2004. So far, this legal act has been change almost 50 times, also in the connection with the necessity of implementing directive 2004/18/EC of the European Parliament and of the Council of 31 March 2004 on the coordination of procedures for the award of certain works contracts, supply contracts and service contracts (Directive 2004/18/EC).

On 26 February 2014, the European Parliament and of the Council accepted new directives concerning public procurement: directive 2014/24/EU on public procurement, repealing directive 2004/18/EC (Directive 2014/24/EU), so called classic directive, as well as directive 2014/25/EU on procurement by entities operating in the water, energy, transport and postal services sectors and repealing directive 2004/17/EC (Directive 2014/25/EU), so called sector directive. As the European Parliament and the Council approved the classical directive and sector directive, there is an obligation to introduce a Polish legal system for their regulations. Pursuant to art. 90 section 1 of the directive 2014/24/EU and art. 106 section 1 of the directive 2014/25/EU, implementation deadlines of both directives into the legal system of the EU memberstates were on 18 April 2016.

On the ground of the Polish legislation, in connection with the obligation of transposition of the regulations of both classical and sector directives, there were revealed two concepts of actions: one aiming at creating one, complex act - Public procurement law, the other meaning regulations novelization of the binding act in the necessary scope. In connection with that, in 2015 the Public Procurement Authority created a project of a new act regulating awarding public contracts. In accordance with the authors' intentions, the goal of the regulation was to create mechanisms allowing the most effective usage of public means, as well as to enable the use of public procurement 
as a means of meeting goals and policies described by the state. Among the most important solutions included in the project, there was indicated - together with regulations simplifying and making more flexible the procedures awarding public contracts - promoting the real use of non-economic goals of procurement contracts. The new solutions would take into consideration in public procurement issues connected with observing social regulations. In January 2016, the Public Procurement Authority went back, however, to the concept of so called small novelization of the act - Pubic Procurement Law. The transfer of the crucial regulations of the directive was done two months after the implementation deadline, i.e. on 22 June 2016 by the Act on act change - Public Procurement Law and some other acts.

In connection with the necessity of the implementation of the regulations of the classic directive, the issue of adjusting Polish national legislation to the requirement of the EU law became of special importance. It is worth paying attention to changes in the area of regulations concerning the issues of so called social aspects of public procurement.

The subject of the study are chosen rights and duties of the local government units as contracting authorities, in the area of realizing social aspects in the organization of public procurement application procedures. For that reason, in analyzed matter the concentration falls on so called classic contracts, while the issues concerning so called sector contracts were omitted, as they refer mainly to the subjects operating in certain areas of economy. The goal of the work is to present sensitive areas of public procurement application procedures covering the problem of subject requirements, requirements as to standing, and offers assessment criteria, in which there was revealed the necessity of a careful transposition of the classic directive regulations concerning social aspects. The study concentrates on so called social clauses, i.e. entries in documentation on public procurement placed by the contracting authority, which include requirements of the contracting authority concerning social aspects.

\section{Financing Optimisation in Public Procurement Tasks}

The term „optimisation” referring to financing public tasks, does not have a legal definition. The term optimisation itself is used in different contexts in legal sciences, including the financial law doctrine. In the literature concerning tax law, there is a commonly used term "tax optimisation”, however in 
practice the term is used in intuitive manner, hence without stating vital for a definition elements (Iwin-Garzyńska, 2016, p. 97-107).

For the needs of this study, the notion of optimisation refers to the choices made by the contracting authorities during the organization of public procurement application procedures, undertaken to realise goals of awarding public contracts. This choices - in accordance with optimisation requirements - are the more appropriate, the more possible appropriate reaching all goals of the public procurement they make. In the accepted understand, optimization has a multi-criteria character.

The analysis of all the goals of the public procurement, whose reaching is the criteria of optimisation, goes beyond the frames of this study. The objective is to emphasise the resent increase of the meaning of social goals in awarding public contracts, and through this emphasise the importance of the criteria as a premise of optimizing financing public tasks.

The issue was noticed in 2015 in the Recommendations of the Council of Ministers on the use of social clauses in public procurement by the government administration (Sprawozdawczość klauzule społeczne). In the document, the Council of Ministers reiterate their conviction that limiting social problems and connecting economic growth with better life conditions are the key tasks of government administration. The vital amount of public means dedicated annually by the government administration to finance the purchase of products, services and building works may have an influence on realisation of social and economic goals of the State. It also justifies intensified actions for a new approach to public procurement. The new approach to public procurement means that public institutions are obliged not only to conduct public expenses according to regulations on public procurement in order to purchase goods, services and building works by keeping the most favourite relation of quality to price, but they should also support the realisation of public policies, including in the range of social policy. Socially responsible public procurement serves taking into consideration different social aspects by the contracting, e.g. the possibility of employment and decent work, social integration, achieving equality of opportunities. It support creating socially aware markets. Binding statutory regulations give the contracting authorities the right to use social clauses by describing additional requirements connected with realisation of public procurement, including the unemployed or minors in order to prepare them vocationally, as well as the disabled. 


\section{Range of Social Clauses Use in Public Procurement}

As shown in the preamble of the classic directive, public procurement plays a key role in the Europe 2020 strategy, set out in the Commission Communication of 3 March 2010 entitled 'Europe 2020, a strategy for smart, sustainable and inclusive growth' (EUROPE 2020) as one of the marketbased instruments to be used to achieve smart, sustainable and inclusive growth while ensuring the most efficient use of public funds. Repealing of the previous directive and introduction of a new one is explained by the necessity to increase the efficiency of public spendings. Also, there is emphasized the need to facilitate the participation of small and medium-sized enterprises (SMEs) in public procurement, as well as enabling procurers to make better use of public procurement in support of common societal goals (Directive 2014/24/EU, point 2 of the preamble).

Indications included in the preamble to the classic directive have their continuation in a normative part. Within its frames, the main place is taken by the issues of regulations of awarding public contracts. The directive constitutes - next to the rule of non-discrimination, transparency and proportionality - the rule according to which memberstates are obliged to undertake appropriate steps which ensure that while realising public procurement, the procurers watch binding obligations in the scope of environmental protection, social and labour law, set in the European and national regulations, in collective agreements or in the international environmental protection law, international social law and international labour law2.

Further regulations of the classic directive concerning social aspects transposed to the Polish legal system may be divided into four groups connected with the organisation of the public procurement procedures: (A) standards concerning description of the subject of the procurement and the realisation of the public contract (so called subject requirements), (B ) standards con-

\footnotetext{
${ }^{2}$ Art. 18 section 3 of the classic directive. Attachment $X$ to the directive includes a list of international conventions within the social and environment al protection laws. It lists among others: ILO Convention No. 87 on Freedom of Association and Protection of the Right to Organise, ILO Convention No. 98 on Right to Organise and Collective Bargaining, ILO Convention No. 29 on Forced or Compulsory Labour, ILO Convention No. 105 on Abolition of Forced Labour, ILO Convention No. 138 on Minimum Age for Admission to Employment, ILO Convention No. 111 on Discrimination in Respect of. Employment and Occupation, ILO Convention No. 100 on Equal Remuneration for. Men and Women Workers for Work of Equal Value, and ILO Convention No. 182 on Prohibition and Immediate Action for the Elimination of the Worst Forms of Child Labour.
} 
cerning conditions of participation in the proceedings as well as premises of the exclusions from the procurement proceedings (so called requirements as to standing), (C) standards concerning assessment criteria of the offers. Another group constitute (D) regulations concerning a separate way of proceedings in case of public contracts of some social services.

\section{Uses of Social Clauses within Subject Requirements}

Regulations of the classic directive, as well as the regulations of Public Procurement Law, which implements it, describing the duties of a contracting institution concerning a correct description of the public procurement subject, can be divided into those in which the legislator (a) imposes on a contracting authority the duty of meeting certain requirements, (b) allows using certain possibilities, and (c) plans certain prohibitions.

An example of restrictions imposed on a contracting authority in description of the public procurement subject is a legal norm included in art. 29 section 2 p.p.l., which implies it is forbidden to describe a public procurement subject-matter in a way which may hinder fair competition, as well as the norm from art. 29 section 3 of p.p.l. which includes prohibition of subjectmatter description by indicating trademarks, patents or the origin, source or a special process which characterizes products or services provided by a certain supplier, if it can lead to favouritism or elimination of some providers or their products.

Interesting in the area of the contracting authority's rights are the regulations of the new classic directive concerning so called technical specifications which are an element of public procurement documentation prepared by a contracting authority. In technical specifications there are described required features of building works, services and supplies. In the directive there are allowed a few ways of forming technical specifications. The first, basically means forming specifications in the categories of performance and functional requirements. The other ways mean forming technical specifications by referring to appropriate norms, but by joining performance and functional requirements with the normative ones (Directive 2014/24/EU, Art. 42). In the directive it is stated that in case when compulsory requirements concerning accessibility are accepted in a legal form of the Union, a technical specification is described - as far as the accessibility for the disabled or designing for all the users are concerned - by referring to the act (Directive 2014/24/EU, Art. 42, section 1). 
On the Polish ground, an example of such an approach to the issue is an amended regulation of art. 29 section $3 a$ of p.p.l., which states that a contracting authority includes in the description of a contract services or building works description, employment requirements in which a contractor or subcontractor is obliged to employ based on a work contract people conducting works indicated by the contracting authority within the procurement realization, if conducting these works means doing work as described in art. 22 §1 of the act of 26 June 1974 r. - the Labour Code.

From the point of view of changes in Polish regulations, it is worth mentioning that according to the amended regulations of p.p.l., description of the subject requirements referring to the issue of employment reaches more vital meaning than before.

Particular attention should be given to the regulations describing exclusion of the rights of a contracting authority concerning the description of the procurement subject-matter. Pursuant to art. 29 section 2 of p.p.l., a contracting authority may give in a procurement subject-matter's description requirements connected with realisation of the procurement, which may include among others social aspects, aspects connected with innovation or employment, especially concerning the employment of: 1) the unemployed, pursuant to the act of 20 April 2004 on employment promotion and labour market institutions; 2) the minors as described in the labour law regulations, in order to prepare them vocationally; 3 ) the disabled, pursuant to the act of 27 August 1997 on vocational and social rehabilitation and employment of the disabled; 4) other people than described in points 1, 2 or 3, pursuant to the act of 13 June 2003 on social employment or to appropriate regulations of the European Union or European Economic Area member states (Szabroński, 2013, p. 157).

The classic directive refers also to the problem of so called labelling (labels). In case contracting institutions are going to purchase building works, deliveries or services of special character (e.g. social), they may in technical specifications, contract awarding criteria or conditions of realising the contract, require a certain label as a proof that building works, deliveries or services have the required characteristics (Directive 2014/24/EU, Art. 43).

The regulation transferring the provisions of the directive is at present art. 30a of p.p.l. It predicts that in case of procurement of special character, a contracting authority may include in the contract subject-matter description, in the offer assessment criteria or in the conditions of realising the procurement, special labelling, if the following conditions are jointly met: 1) requirements concerning labelling refer only to criteria which are connected 
with the procurement subject, and they are appropriate for describing the characteristics of building works, deliveries or services which are the subject matter of the procurement; 2) requirements concerning labelling are based on criteria which are possible to be objectively checked and which are nondiscriminatory; 3) conditions of awarding labelling are accepted in open and transparent procedure, in which all interested subjects can participate, including the subject which belong to public administration, consumers, social partners, manufacturers, distributors and non-government organizations; 4) labelling is accessible to all interested parties; 5) requirements concerning labelling are described by the third party, and the contractor applying for labelling cannot have a decisive influence on them.

\section{Use of Social Clauses within the Frames of the Requirementsas to Standing}

As mentioned before, the participation of contractors in the procurement proceedings is also connected with the need to verify their as to standing qualifications, referring for ex ample to certain qualifications, personnel potential, experience they have, but also the lack of circumstances disqualifying the contractor from the participation in the procurement proceedings.

In the content of the preamble to the classic directive there is also a reference to the issue of exclusion of the contractors because of so called "social obligations". Pursuant to the recital 101 of the preamble, contracting institutions should have the possibility to exclude contractors who turned out to be unreliable, for example by violating social obligations,, including regulations concerning accessibility for the disabled.

Pursuant to art. 57 section 4 item a) of the classic directive, institutions may exclude or be obliged to exclude from the participation in proceedings to be awarded a public contract when the contracting authorities, by any means, may prove violation of the applicable obligations, as described in art. 18 section 2 of the directive, i.e. among others, the obligations concerning social law.

In p.p.l, the reflection of the rule is art. 24 section 5 item 7) specify the possibility of the exclusion of a contractor who was issued a final administrative decision concerning the violation of obligations resulting from the regulations of the labour law, environmental protection law or social security regulations, if together with the decision the fine not less than 3000 PLN was given (Szabroński, 2013, p. 158-159). 
The indicated exclusion premise is not obligatory. Its use depends on whether the contracting authority specifies such possibility in the given procurement proceedings.

Requirements as to standing include also positive conditions, on fulfilling which the participation of the contractor in the procurement proceedings depends.

In accordance with the content of the directive, employment and work are key elements which guarantee equal chances and which help to integrate the society. That is why the role of sheltered workshops and of the subjects leading so called "social economic activity” are noticed. However, the participation of such subjects in procurement in normal competition conditions is difficult. That is why the directive specifies that the memberstates may stipulate that the right to participate in procurement proceedings or to part of them is given only to such institutions or to other subject from the area of social economy. The contracting authority should also have the possibility to stipulate the necessity of contract realisation for the sheltered employment programmes (Directive 2014/24/EU, Recital 36 of the preamble).

Directive's recitals have their expression in art. 20 concerning so called reserved contracts. According to it, the memberstates may stipulate, among others, the participation in procurement proceedings for the sheltered workshops and contractors whose main aim is social and vocational integration of the disabled and disfavoured.

Based on the Public procurement law, the example of such a solution is the possibility to make a stipulation that the public contract may be awarded only to sheltered workshops and other contractors whose activity, or activity of their organisational units which are to realise the contract, covers social and vocational integration of people who are members of socially marginalised groups, especially the disabled, unemployed people deprived of personal freedom or released from prisons, who have problems with the integration with their environment, the homeless, refugees, people under 30 or right after 50 who are registered as seeking employment, people without employment, as well as the members of minority which is in an unfavourable situation, especially of national and ethnic minorities (Public procurement law, Art. 22 section 2).

\section{Use of Social Clauses in Offers Assessment Criteria}

Among offers complying with the requirements set by a contracting authority, filed by the contractors meeting the conditions of participating in 
proceedings, the contracting authority makes the choice of the most advantageous offer. The contracting authority uses offers assessment criteria, being directed by the rules described in the public procurement regulations.

The basic rules ordering contracting authority's use of offers assessment criteria is the rule of a free choice of criteria by the contracting authority and the rule according to which the criteria have to refer to the subject-matter of the procurement. Keeping the freedom of criteria choice rule, art. $91 \mathrm{sec}-$ tion 2 of p.p.l. show example criteria of the offers assessment, among which it enumerates social aspects, including vocational and social integration of certain groups, so called disfavoured people, who were mentioned above in connection with the requirements as to standing.

The issue of offers assessment criteria is undertaken in the new classic directive. Article 67, concerning contract award criteria states that contracting institutions base offer awarding on the offer which is economically most advantageous, the while the economically most advantageous offer is described based on price or cost, using the approach based on cost effectiveness, such as life-cycle-costs (Guidelines for Social Life Cycle Assessment of Products).

The economically most advantageous offer may encompass the Best ratio of quality to the price, which is estimated based on criteria covering different aspects, including social ones.

In accordance with provisions is necessary to analyse the feasibility of establishing a common methodology in the area of the calculation of social life cycle costs, taking into consideration the existing methodologies, such as „Guidelines for Social Life Cycle Assessment of Products” approved within the United Nations Environment Programme (Guidelines for Social Life Cycle Assessment of Products).

The issue of the calculation of life cycle costs is undertaken in art. $91 \mathrm{sec}-$ tions $3 b-3 d$ amended by p.p.l. Unfortunately, the content of the article does not refer to the social aspects.

\section{Conclusions}

Accepting on 26 February 2014 by the European Parliament and the Council a new directive concerning procurement and the necessity to transposition its provisions to the Polish legal system caused the appearance of vital changes in the area of procurement referring to social aspects. The most momentous changes are connected with the specified in regulations possibility 
to describe a subject-matter of the contract including social requirements. Next change concerns premises concerning contractor's exclusion from procurement proceedings as a result of the violation of social obligations and the possibility of forming conditions of participating in proceedings referring to the employment of disfavoured people. Completing the changes is the possibility of forming offers assessment criteria referring to social aspects, which is specified in the amended act.

It is worth emphasising the fact that all presented changes do not impost obligations on the contracting authorities, but they specify the possibility of undertaking certain actions within the organisation of the procurement proceedings. At present, contracting authorities each time have a choice whether to introduce social clauses to given proceeding or not. Their possible introduction determines the course of procurement application proceedings, influences the way contractors' offers are prepared, including prices and contract realisation costs calculations. It means that social aspects remain a momentous, yet facultative premise of the optimisation of the public expenses within public contracts.

\section{References}

Directive 2004/18/EC of the European Parliament and of the Council of 31 March 2004 on the coordination of procedures for the award of certain works contracts, supply contracts and service contracts, Official Journal of the European Union L 134 of 30.04.2004, p. 114.

Directive 2014/24/EU on public procurement, repealing directive 2004/18/EC Official Journal of the European Union L 94 of 28.03.2014, p. 65.

Directive 2014/25/EU on procurement by entities operating in the water, energy, transport and postal services sectors and repealing Directive 2004/17/EC Official Journal of the European Union L 94 of 28.03.2014, p. 243 as amended.

EUROPE 2020 A strategy for smart, sustainable and inclusive growth, http:// ec.europa.eu

Guidelines for Social Life Cycle Assessment of Products of United Nations Environment Programme, http://www.unep.fr/shared/publications/pdf/ DTIx1164xPA-guidelines_sLCA.pdf (accessed 30.03.2017 r.).

Iwin-Garzyńska J. (2016). Nowe oblicze optymalizacji podatkowej w Polsce, Finanse, Rynki Finansowe, Ubezpieczenia (83), part 1.

Panasiuk, A. (2007). Publicznoprawne ograniczenia przy udzielaniu zamówień publicznych, Bydgoszcz, Oficyna Wydawnicza Branta. 
Public finances law, Dz. U. /Journal of Law/ of 2013, item 885 as amended.

Public procurement law (consolidated text: Dz. U. /Journal of Law/ of 2015 item 2164 as amended.

Recommendations of the Council of Ministers on the use of social clauses in public procurement by the government administration, https://www.uzp.gov. $\mathrm{pl} /$ baza-wiedzy/analizy-systemowe/sprawozdawczosc-klauzule-spoleczne

Sprawozdawczość klauzule społeczne: https://www.uzp.gov.pl/baza-wiedzy/analizy-systemowe/sprawozdawczosc-klauzule-spoleczne (accessed 30.03.2017 r.).

Szabroński, S. (2013). Klauzule społeczne w zamówieniach publicznych a zrównoważony rozwój lokalny, Warmińsko-Mazurski Kwartalnik Naukowy, Nauki Społeczne, Issue 1.

The Act on act change - Public Procurement Law and some other acts, Dz. U. /Journal of Law/ of 2016 item 1020. 